\title{
Mehmet Aça*
}

\section{Social Status and Roles in Proverbs of Lithuanian Karaims and Proverbs of Anatolian Turks}

DOI: http://dx.doi.org/10.12775/LC.2020.014

\section{Introduction}

ndividuals' being able to continue their existence in society within which they are born depends on their status which that society has assigned to them or they themselves has obtained and on performing their role that is as required by their status. Humans trying to determine their place or position within society with decisions which are made by them have also to fulfil some requirements which are brought by social life. In Tolan and et al. words, the individuals continuing their relationships on the basis of their requests and social imperatives can describe themselves over their positions. These positions are called as role and status. While status determines the individual's position and degree within a group, the role means behaviours which are asked for/requested or expected from people having certain statuses (Tolan et al. 1985: 227). To open the subject up more from Yörükân:

[... ] status refers to a position (place), and on the other hand, role to certain behaviours, attitudes and values, which are done by the individuals in relation to their status that is occupied by them. According to this, the role is behavioural patterns which the individuals have to do as per certain norms or they deems appropriate to be done and they could do, and which others

* Prof. Dr. of Marmara University Faculty of Arts and Sciences, Department of Turkish Language and Literature, Istanbul, Turkey.

E-mail: mehmet.aca@marmara.edu.tr|ORCID: 0000-0003-3132-4086. 
request from them as the right or expect from them as is required by their status. Individuals are obliged to do these role behaviours which are determined by norms, values, manners, customs and laws, of society so that they can maintain the ascribed or the achieved status. Otherwise, they are regarded as strange or odd, become ridiculous, or they are punished in various ways (Yörükân 2015: 108-109).

Described by Marshall (1999: 697), in the weak sense, as the position (teacher, priest etc.) where a person occupies in social structure, and in the strong sense, as a social stratification in which status groups and strata are graded and organized by legal, political and cultural criteria, grouping and integrating status(es) with these statuses-bound roles (stereotyped behaviours) around a number of basic needs constitute social institutions or structures (Yörükân 2015: 109). Family is the leading one of these social institutions or structures. Members who constitute the family have certain statuses and take on these statuses-bound roles. Mother, father and children (siblings) constituting the family are liable to adopt statuses which both the needs bring about and the society assigns to themselves and to perform appropriate roles for these statuses. Father performs roles that are as required by the father status; mother by the mother status; and children perform roles (roles of childhood and siblinghood) by both the child status and that of the sibling. For example, father has a status based on authority, masculinity and extroversion in traditional societies and accordingly, his role („paternity role”) is to fulfil all requirements (to represent the family, to work, to ensure safety, to protect the honour and so on) of fatherhood and to exhibit suitable behaviours for paternity status. The role of mother (maternity role) who has a status including obedience, femininity and introversion is to manage household, raise and train children and not to injure male's honour. The family institution, by its nature and structure, brings about kinship institution, as well. For this reason, specialists who classify statuses also include the status which is shaped on family and kinship basis into their classifications. By the way, it needs to state that social structure consists of thousands of statuses belonging to various areas, however, that specialists gather these statuses under four main groups. These statuses are the ones which are shaped according to age\&gender, family and kinship, occupations and the affiliate or the affiliated societies and clubs.

Classified statuses and roles as „ascribed” and „achieved”, Yörükân implied, by the former, statuses and roles, whether they are biological, or completely social- or culturalorigin, which are imposed even at birth (imposed by cultural norms or expectations) without enfranchising the right to choice, beyond the individual's control, such as "age” (child, adolescent, young, middle age, old; biological age, physiological age, sociological age, psychological age), „gender” (female, male), „family-kinship” (mother, father, sibling, uncle and so on); by the latter, the ones which the individuals acquires with their choices, special abilities or with making a certain effort by themselves. Worker, head worker, civil servant, administrator etc. fall within the scope of the achieved statuses and roles (ibid.: 120-127).

Also classified by Yörükân (ibid.: 129-137) according to their rigidities or flexibilities, degrees of continuity and repetition, volumes, degrees of significance and of providing prestige, convenience and difficulty degrees to which they provide in terms of practice, and to principles of comprehending sense of the role, roles make cultural norms fullfilling, as well. In other words, also norms are an inseparable part of statuses and roles. They state 
emotions, attitudes and the expected behaviours, which status-holder individuals should learn and fulfil ${ }^{1}$.

In brief, statuses, whether they are ascribed or achieved, require execution of certain roles. The execution of roles depends on emotions, attitudes and the expected behaviours, which people should learn and fulfil. Individuals have to perform these role behaviours which had been determined by norms, values, manner, customs and laws, of the society so that they can maintain their statuses. Unless individuals performed, they would be regarded as strange or odd, become ridiculed and be punished in various ways.

While some of statuses and roles which also reflect social values are ascribed through various institutions, including family, some of them are acquired (achieved) based on oppurtunities and abilities. Roles that are as required by statuses, whether they are ascribed or achieved, are conveyed and reminded to individuals on miscellaneous environments on various occasions. Family and society also often benefit from oral literature works in conveying and reminding statuses-bound roles. In conveying and reminding roles and statuses, significant duties fall to also proverbs of which are the leading products of oral culture and which reflect value judgments of societies and their world views. Proverbs, presenting strikingly the basic judgements which are constituted after long observations\&experiences and the principles which are connected to these judgements (Elçin 1993: 623-632; Elçin 1997: 413-428), oftenly emphasize on the role of execution of statuses and these-bound roles in maintaining society life harmoniously and balancedly, as well. In the study, reflections of Lithuanian Karaims' status and role perceptions on their proverbs will be determined and interpreted. Through proverb examples emphasizing on statuses and roles, a comparison of Lithuanian Karaims (of Karaims faith)' status and role perceptions with those of Anatolian Turks will be made, too.

It was mentioned above that statuses focus mainly on age, gender, family, kinship, working and occupation, and roles mean behavioural patterns which the individuals have to do as per certain norms or they deems appropriate to be done and they could do, and which others request from the individuals as the right or they expect from the individuals as is required by their status. For this reason, reflections of Lithuanian Karaims' perceptions regarding statuses and roles on their proverbs will be determined and interpreted through value judgments-, gender-, family-, kinship-, working- and occupation-themed proverb examples. Priority will be given to reflections of Lithuanian Karaims' some value judgements on their proverbs, since they have an importance place in constituting social norms.

1 Marshall defines "norm" as a shared expectation of behaviour that connotes what is considered culturally and appropriate. Norms are similar to rules and regulations in being prescriptive, but they lack formal statuses of rules. The concept is intimately linked to social regulation, social control and social order. According to the social identity theory, norms (rather than personal beliefs) are an expression of perceptions for what actions will enable other people to approve an identity. Therefore, it is thought that people conform to norms in order to prove both to themselves and to others that they are certain kind of people (Marshall 1999: 533-534). 


\section{Proverbs of Lithuanian Karaims and Value Judgments}

As norms state emotions, attitudes and the expected behaviours, which status-holder individuals should learn and fulfil, reflections of some value judgments on proverbs of Lithuanian Karaims, having an important place in constituting norms, will be taken a look in short before statuses and roles.

It is seen that, when it comes to value judgments, proverbs of Lithuanian Karaims highligh the commitment to customs; obeying to the etiquette; avoiding from greediness, stinginess, jealousy and foolishness; preferring generosity, modesty; attaching importance to the mind and knowledge; rendering the trust or the job to the one whom he/she is due (i.e., to the competent person); friendship, good neighbourhood relations, parental love and so on. For proverbs of Lithuanian Karaims ${ }^{2}$, greediness brings about insanity (Aç közlügü bulğäyt miyin/His/her greediness brings him/her insanity $)^{3}$, jealousy about insatiateness (Künüçü adam barça toyumsuz/Jealous person is always insatiable, Opxax barça aç/ The greedy is always hungry, Opxaxka barı az/Everything falls short to the greedy). According to proverbs of Lithuanian Karaims, regarding knowledge as more valuable than treasure (Bilüv xaznadan yaxşırax/Knowledge is more valuable than treasure), condemning not learning worse than not knowing (Xor bilmäskä-betär bilinmäskä/Not knowing is bad, but, not learning is worse $)^{4}$, drawing attention to the fact that giving advice to the fool is in vain (Ayt teligä ügüt-kabunur moro kügürt/If you gave advice to the fool, he/she would catch fire as if he/she were sulphur), recommending using the mind instead of tongue (Try tiliyni, kozğa miyiyni/Hold your tongue, move your brain) and advising consulting the wise (Sor usludan, tüvül yelbaşlıdan/Ask from the wise, not from the unwise) ${ }^{5}$, it is not possible for the empty sack, in other words, ignorant, worthless and effortless human to stand (Boş kapçux turalmast/ an empty sack cannot stand upright) ${ }^{6}$.

According to proverbs of Lithuanian Karaims drawing attention to the fact that the trust should be rendered to the one whom he/she is due or the job should be made to a competent person, by saying (Börügä bermä koynu kütmä/Do not give sheep to wolf to herd $)^{7}$, to make an effort to the empy and wastrel man is as meaningless as trying to drive

\footnotetext{
2 Proverb examples used in the study were cited from Dubiński (1994: 235-248).

3 Anatolian Turks try to tell catastrophes which are caused by greediness with the proverb "Deveyi yardan uçuran (atan) bir tutam ottur" (,the thing which causes the camel to fly from (jump off) cliff is a pinch of grass"); cf. Aksoy 1988: 239.

${ }^{4}$ Anatolian Turks draw attention to this situation with the proverb "Bilmemek ayıp değil, sormamak (öğrenmemek) ayıp" ("There is no shame in not knowing; the shame lies in not finding out [not learning])" (ibid.: 189).

5 Anatolian Turks draw attention to the importance of the mind and the clever with these proverbs: "Akıl kişiye (adama) sermayedir" (",Mind is capital [wealth] to person/man"), "Akıl akıldan üstündür" ("One mind is more superior to another mind [two heads are better than one])" (ibid.: 128), "Akıllı, söylemeden düşünür, akılsız düşünmeden söyler" ("Wise man thinks before he speaks, but foolish man says without thinking”); ibid.: 130.

6 Also Anatolian Turks emphasize that ignorant, worthless and effortless people will not stand, with the proverb "Boş çuval ayakta (dik) durmaz" („An empty sack cannot stand [upright)”); ibid.: 204.

7 Anatolian Turks draw attention to this situation with the proverb “Kedinin boynuna ciğer asılmaz" ${ }_{\text {„I }} \mathrm{A}$ liver is not hung around a cat's neck"); ibid.: 354.
} 
the nail on the punk wood (Çirik baylan-anda bağatırlan/the nail is wasted for the punk wood) $)^{8}$.

Proverbs of Lithuanian Karaims which regard friendship and neighbourhood relations as important in terms of the continuity of social order lay emphasis on the friendship by saying (Yaxşı dost-tapxan xazna/A good friend is treasure found and Altın bahalıxta, adam dostluxta/Gold is understood in carat, human in friendship) ${ }^{9}$; and on the neihgbourhood by saying a good neighbour is more valuable than brother (Yaxşı konşu- karandaştan baharax/; (Yaxşı konşu yırax karandaştan baharaxtır/A good friend is more valuable than the brother far away; Kaç yılandan da xor konşudan/Escape from snake and bad neighbour and Korxma şıytandan-korx yaman konşudan/Don't be scared of the devil, but scare the bad neighbour $)^{10}$.

Proverbs of Lithuanian Karaims which state that they place importance on the effort, working, producing and richness, by saying (Axça kolga-etmäk avuzğa/Money to the stranger, bread to the mouth, Aşsız tirilmäs-işsiz yemlämäs/There is no life without meal, and no meal without effort and Bersey yergä- xoca bolurs yemgä/If you gave to the ground, you would get rich to meal), show meaninglessness and bad results of boasfulness by saying (Maxtançäxnın boşçölmägi/Boasful man's pot is empty).

We can say Lithuanian Karaims whom are understood to be quite sensitive to manners and traditions from the proverb (Adet-yarım dinnin/The manner is half of religion) ${ }^{11}$ attribute the sustainability of social life in harmony and balance to collective acceptances and behaviours. Expectations of Lithuanian Karaims for collective acceptances and behaviours show themselves in proverbs which focus on social statuses and roles, as well.

\section{Gender-Focused Statuses and Roles in Proverbs of Lithuanian Karaims}

When reflections of gender-focused statuses and roles on proverbs of Lithuanian Karaims have been examined, it is seen that a particular attention is paid on the status of the woman and this-bound role of her. Proverbs of Lithuanian Karaims, which draw attention to that the beauty one of the girl should be at work, but not through the window (Körkü kıznın iştätüvül terjädä/The beauty one of the girl is at work, but not through the window), the skillful

\footnotetext{
8 Anatolian Turks state that making an effort to the man who is wastrel and whose essence is corrupted is meaningless, with the proverb "Çürük tahta çivi tutmaz" („Punk wood keeps no nail”); ibid.: 255.

9 Also Anatolian Turks draw attention to the importance and value of friendship with the proverbs "Kazanırsan dost kazan, düşmanı anan da doğurur" (,Win friend if you win, otherwise, also your mother can birth to the enemy") (Ibid.: 352) and "Sadık dost akrabadan yeğdir" („Loyal friend is better than the relative (loyal friend is preferable to the relative)"); ibid.: 419.

10 Anatolian Turks draw attention to the importance of good neighbour with these proverbs: "Ev alma, komşu al" ("Get the right neighbours rather than the right house”), ibid.: 277; “Komşun kötüyse göç kurtul, dişin ağrırsa çek kurtul” ("move house and get off if your neighbour is bad; have out and get off if you have a toothache") (Çobanoğlu 2004: 354).

11 Anatolian Turks express this issue rather over proverbs containing value judgments and customs: "Ataların sözü Kura'n'a girmez; ama yanınca yürür." („Sayings of ancestor do not get into the Qoran, but walk beside it”) (Aksoy 1988: 159).
} 
one of the girl is understood from her hand and spandle (Kıznın tuvuşluğu, koluba urçuğu) Skillfulness of the girl is her hand and spandle), the girl from whose mother is snake should be stayed away (Ana ilan-kızindan aylan/If the mother is snake, stay away from her daughter) and that the mother should be firstly looked at before wiving the daughter (Anasina bağın-kızın al/Wive the daughter after looking at the mother) ${ }^{12}$, affirmed the skillful wife (Yetiz katın-ergä altın/The skillful wife is gold to the husband, Katınıy tuvuşlu-uprağıy yaravlu/your wife is skillful, then your apparel suits) and the wife of character (Katın kılıxster tınçlixsız/The characterless wife, then the unpeaceful husband) ${ }^{13}$. As is also understood from examples of proverbs, the husband's peace and interests have been taken into consideration on features which make the woman positive (skillfulness, hardworkingness, nobleness, morality): While the skill wife is treasure for the husband/male, the characterless wife is the source of intranquility.

Examples from proverbs show that Lithuanian Karaims' perceptions on status and role of the woman reflect the point of view of a male-dominant society, and this is not too different from those of The Muslim Turks living in Anatolia. It is not alone enough to explain this similarity in perception concerning status and role of the woman with the fact that both Turkic groups (Lithuanian Karaims and Muslim Turks in Anatolia) come from common origin and past, they are living on same cultural geography and that they are being nourished from same cultural resources. We should also seek reasons of this similarity in the fact that Karaims and Islam, emerged in the same geography, rather consider the woman in a male-centered (androcentric) way.

\section{Family-and Kinship-Focused Statuses and Roles in Proverbs of Lithuanian Karaims}

Family institution which has an important place in adopting for individuals' statuses and roles is built on good and the balanced relations between parents and children. For this reason, while parents should be a good role-model for their children, children should know their parents' value and should be respectful to their parents. As a matter of fact, a Lithuanian Karaim proverb has drawn attention to the fact that mothers should be a good role model for their daughters, by saying (Yaxşı ana- sıy kızına/Good mother is honour to her daughter). Proverbs of Lithuanian Karaims, drawing attention to that mothers should be a good role model for their daughters, have laid stress on the importance of parents in determining statuses and roles of children, ie., in being good individuals for them, by saying (At balast-at, it balast-it/Foal becomes horse, and puppy becomes dog $)^{14}$. When taking into

\footnotetext{
12 Anatolian Turks state this situation with that proverb: "Anasına bak kızını al, kenarına (kıyısına, tarağına) bak bezini al" (,Wive the daughter after looking at the mother, and buy the fabric (cloth) after looking at the edge (card) of it"); ibid.: 147.

13 Anatolian Turks state relationship between husband's peace\&happiness and his wife with that proverb: "Kadın kocasını isterse vezir, isterse rezil eder" („Wife either makes his husband vizier or breaks him) or “Kocasını vezir eden de rezil eden de karısıdır" („A good wife is a good prize”); ibid.: 340 .

${ }_{14}$ Anatolian Turks draw attention to this issue with this proverb "Cins cinse çeker" / "Soydur, çeker" (,The kind takes after the kind" / "That is lineage, so it takes after"); ibid.: 431.
} 
consideration the fact that children begin to possess statuses and roles starting from the family milieu and that they maintain their social lifes based largely on instruction and training which they take from their families, it is better understood why the said proverb has tried to draw attention to statuses and roles of parents.

The Lithuanian Karaim proverb, which says (Tilsiznin tilin anası anläyt/The mother understands dumb person's tongue $)^{15}$, is further remarkable in that communication between mothers and children is not only based on speech and act, but it is also a bond and communication established upon emotion, love and understanding between them.

The proverb of Lithuanian Karaims, drawing attention to the fact that children understand their parents' value while generally they are raising their own children, by saying ( $A n-$ lar ataba anani, östürä öz ulann/The child would understand his/her parents' value when he/she raised his/her own son), has tried to state that some statuses and roles (parents' statuses, in particular) will be understood much better when the same roles have been undertaken by the children, on the other hand.

Also in the proverb for Lithuanian Karaim saying (Özününkü çançat, aylanıp kuçat) Your relative stings, then turns and embraces), it is possible to see a similar one of negative judgments, with regard to the relatives, which correspond the reflection in proverbs of Anatolian Turks, such as “Emmim dayım, hepsinden aldım payım” („My paternal uncle, maternal uncle, I got bitten by all of them”), "Akraba ile ye iç, alışveriş etme” („Eat and drink with the relatives, but don't do business with them"), "Akrabanın akrabaya akrep etmez ettiğini” („Even scorpion would not do what a relative would do to another relative”) (Aksoy 1988: 132) etc. In the said proverb, the relative was likened to a stinging scorpion (metaphor). The only difference between the relative and the scorpion is that the relative hugs the person (other relative) whom the relative stings as if nothing has happened, and that the relative tries to console that person.

\section{Working- and Occupation-Focused Statuses and Roles in Proverbs of Lithuanian Karaims}

Effort, working and production have an importance function in maintaining social life in a healthy and orderly way as well as for individuals to possess status and role. In other words, the indivuals require to contribute to the production, to have possession of a job or an occupation and to duly perform their jobs or occupations so that they can become a status- and role-holder. Individuals "who are unable to find a job (unable to handle to an axe)" - in the words of Anatolian Turks-are able to make it difficult that the social life is maintained in order and harmony. Hence, proverbs of Lithuanian Karaims which say that the daytime is working time, and the night is dreaming time (Kün işlärgä-keçä tüşlärgä/The daytime is for works, the night is for dreams) frequently emphasize on working- and occupation-focused statuses and roles. Proverbs of Lithuanian Karaims which draw attention

15 In Anatolian Turks: “Dilsizin dilini anası anlar" („The mother understands from the dumb person's tongue/ The dumb person's tongue is understood by the mother"); cf. Çobanoğlu 2004: 216. 
to that; there will be no life without meal and no meal without effort (Aşsiz tirilmäs-isssiz yemlämäs/There is no life without meal, no meal without effort); God will give if begged, but it needs to fetch the endowed, i.e., to work (Tenri berir-yalbarma keräk, yuvga keltirmästbarip alma keräk/God gives, it needs to beg, but He doesn't bring it at home, so it needs to fetch); stomach will not be full without money (Axça kolga-etmäk avuzğa/ Money to the stranger, bread to the mouth ${ }^{16}$; peace of mind will be able to possible with fullness of the stomach (Karında toxlux-başında boşlux/Fullness in stomach, so freeness in the head); the non-working hungry man might only imagine the meal in his dream, (Aç börüdä-süväkler tüşündä/Hungry wolf imagines the bone in his/her dream $)^{17}$; it needs to work very hard sleeping little (Az et çirimni-estä tut işiyni/ Sleep little, keep your work in your mind); the working man will be full to meal (Kalmasäy iştän-toyars etmäktän/If you don't fall behind in the work, you will be full to bread); the one who has laid down on the job will have difficulty in finding bread (Taşlasäy işiyni-inäbä aşars etmäkni/If you have laid down on the job, you will eat the bread with needle); and that the debt sinks man (Borç borçlunu batırat/The debt sinks the debtor $)^{18}$, have emphasized job- and occupation-focused statuses and roles over agriculture and gardening, rather. The following proverb examples are of the quality that proves this situation:

Bersey yergä- xoca bolurs yemgä/ If you gave to the ground, you would get rich to meal.

Bitsä aşlıx-kaçar taslıx/If barley grew, poverty would go away.

Boş baxça-yox axça/ Empty garden, no money.

Baxça xıyarsız-yubiy axçasız/ Garden without cucumber, the penniless owner.

İlasäy çaçxanda- kuvanırs kaxkanda/ If you cried while planting, you would rejoice while harvesting.

Indırıy tolu- yukuy tatuvlu/Your full of grain bin, your sweet sleep.

Saban koluyda-etmäk ambarda/ Your plough is at your hand, the bread is in the grain bin.

Sabanda yuvuş kölmäk-ambarda tolu etmäk/ Wet shirt on the plough, full of bread in grain bin.

Proverbs of Lithuanian Karaims which emphasize generally job- and occupationfocused statuses and roles over agriculture and gardening do this function over the fishery profession, as is also understood from the proverb example (İbitmäsey artiyn, tutmas balixnl/If you did not wet your back, you wouldn't catch the fish).

\footnotetext{
${ }_{16}$ Anatolian Turks draw attention to the relationship between effort/working and bread/eating by saying "Toprağı işleyen, ekmeği dişler" („whoever cultivates the soil, that one eats bread”) (Aksoy 1988: 450) and "Emek olmadan (emeksiz) yemek olmaz" („No pain, no gain/there ain't no such thing as a free lunch”); ibid.: 267.

17 In Anatolian Turks: “Aç tavuk düşünde kendini darı ambarında görür" (, Hungry hen imagines herself being in millet bin") (Çobanoğlu 2004: 49).

18 Anatolian Turks try to tell the borrower's situation by saying "Borçlunun dili kısa gerek" ("Tongue of the borrower should be short”) (Aksoy 1988: 202), "Borçlunun döşeği ateşten olur” („Borrower's bed is made of fire”) (ibid.: 202), "Arpacıya borç eden, ahırını tez satar" ("Whoever got into barley seller, then that person would sell the barn") (ibid.: 153) and "Borca içen iki kez (kere) sarhoş olur" („Whoever drank to the debt, then that person would get drunk twice") (ibid.: 201).
} 


\section{Conclusion}

Like proverbs of Anatolian Turks, from which we included examples in our study, proverbs of Lithuanian Karaims regard, as one of basic duties, teaching and reminding that individuals should possess position within the society, they should behave properly to these positions which are ascribed to themselves or which they have achieved by working, in other words, they should perform suitable roles for their positions. When considered social life should be maintained in order and harmony over status- and role- holder individuals, it will be seen that it is a necessity for proverbs of Lithuanian Karaims to emphasize on values, statuses and roles.

Just like proverbs of Anatolian Turks focusing on statuses and roles, proverbs of Lithuanian Karaims concentrating on statuses and roles take as a goal getting individuals to adopt value judgments, too. As is also understood from the limited number of examples, proverbs of Lithuanian Karaims underline that value judgments, such as the commitment to customs, to obey the etiquette, to avoid from greediness, stinginess, jealousy and foolishness, to attach importance to the generosity, the modesty, the mind and to the knowledge, to render the trust/the job to the competent one, friendship, good neighbourhood relations, parental love etc., are important in adopting statuses and performing roles.

Although roles and perceptions which reflect on their proverbs of Lithuanian Karaims contain resemblances with those of Anatolian Turks, they also have an universal character. This situation, in our opinion, is due to the fact that humanity has common value judgments and expectations of similar statuses\&roles.

Proverbs examples drawing attention to women's statuses and roles show that perceptions of Lithuanian Karaims with regard to women's statuses and roles are not too different from those of other Muslim Turks living in Anatolia. However, this evaluation which has been done based on limited numbers of proverb examples needs to be supported by much more comprehensive studies for oral tradition.

Proverb examples which are built on working- and occupation-based statuses and roles show that effort, production, hardworkingness and having possession of an occupation (i.e., being an occupation-holder) have an important role in Lithuanian Karaims' status and role perceptions. Non-working and non-producing individual, on one hand, will debar himself/herself from becoming status- and role-holder, he/she will disrupt social life established on harmony and balance, on the other hand.

In conclusion, we must state that superficial value-, status- and role-focused evaluations based on limited number of proverbs which were cited from Dubiński should be made more meaningful and functional by also taking other oral culture products, traditional beliefs and practices into account. Comprehensive and in-depth studies which will be done on Lithuanian Karaims' oral culture products, traditional beliefs and practices will provide that not only their perceptions with regard to statuses and roles, but also their general worldviews are learned better. 


\section{Bibliography}

Aksoy, Ömer Asım 1988. Atasözleri ve deyimler sözlüğ̈̈ 1 atasözleri sözlüğ̈̈. İstanbul: İnkılâp.

Çobanoğlu, Özkul 2004. Türk dünyası ortak atasözleri sözlügü. Ankara: Atatürk Kültür Merkezi Başkanlığı Yayınları.

Dubiński, Alexander 1994. Caraimica. Prace karaimoznawcze. Warszawa: Wydawnictwo Akademickie „Dialog”.

Elçin, Şükrü 1993. Halk edebiyatına giriş. Ankara: Akçağ Yayınları.

— 1997. „Türk dilinde atalar sözü”. In: Halk edebiyatı araştırmaları II. Ankara: Akçağ Yayınları.

Marshall, Gordon 1999. Sosyoloji sözlüğü. Transl. Osman Akınhay [\&] Derya Kömürcü. Ankara: Bilim ve Sanat Yayınları.

Tolan, Barlas [\&] Galip İsen [\&] Veysel Batmaz 1985. Ben ve toplum sosyal psikoloji-1. Ankara: Teori Yayınları.

Yörükân, Türkan 2015. Alfred Adler sosyal roller ve kişilik. 4th edition. İstanbul: Türkiye İş Bankası Kültür Yayınları. 